\title{
The Politics of Law on Wage Systems In Indonesia
}

\author{
Teguh Pribadi Made Warka Krisnadi Nasution \\ Faculty of Law, Universitas 17 Agustus 1945 Surabaya, Jalan Semolowaru 45 Surabaya Indonesia
}

\begin{abstract}
Indonesian Politics of Law in terms of wages must pay attention to the value system, ethics, and unwritten law. Each community has certain goals to be accomplished by its members. To achieve these goals, there are facilities provided that can be used, but in reality, not everyone can use these available facilities. This situation causes the use of inappropriate means in achieving goals and will arise irregularities in achieving goals. The existence of social classes and structures in society causes different opportunities for achieving goals. It is often seen that wage policies in Indonesia still reflect on the differences between the lower class and higher class (upper class)". These class differences and opportunities are the main factors of the tug-of-war between workers and employers in the demands of increasing minimum wages each year. It happens because both parties have their own different interests. For that, legal instruments must be able to be used as guidelines in determining and stipulating wages of workers to meet the needs for workers and their families, so as to improve the quality, role and position, and protection of workers according to human rights.
\end{abstract}

Keywords: goals, wage system, minimum wages

DOI: $10.7176 / \mathrm{JLPG} / 88-02$

Publication date: August $31^{\text {st }} 2019$

\section{A. INTRODUCTION}

The wage system in Indonesia is a very crucial problem in the area of labor, even the handling of wages is often the cause of disputes and encourages strikes and demonstrations. The handling of wages is not only about the technical and economic aspects, but also the legal aspects that underlie the matters relating to wages are carried out appropriately based on applicable laws and regulations.

Politics of law, which is the basic policy dimension in the wage sector, is a fundamental thought for the making of regulations regarding wages. It is instrumental for making the law that will be used in the stipulation of wages for workers to meet the needs of decent living for them and their families, to improve the quality, role and position, and protection of workers according to the rights in the workforce.

Indonesian Politics of Law in terms of wages must pay attention to the value system, ethics, and unwritten law. Each community has certain goals to be accomplished by its members. To achieve these goals, there are facilities provided that can be used, but in reality, not everyone can use these available facilities. This situation causes the use of inappropriate means in achieving goals and will arise irregularities in achieving goals. The existence of social classes and structures in society causes different opportunities for achieving goals.

It is in accordance with what is said by Made Darma Weda, that "The lower class has a smaller chance of achieving goals compared to the upper class". ${ }^{1}$ In addition, the class differences and opportunities can also be a factor of disharmony between workers and employers every year, due to demands for the increase of the wages.

Wage policy in Indonesia has always been based on minimum wages that focus on the decent living needs of laborers/unmarried workers with work periods of under one year. But it does not include those who have worked for more than 1 (one) year and have a family. Therefore the legal policy of wage policy must be directed at fulfilling the needs of decent living for workers and their families to improve the quality, role and position, and protection of workers in accordance with human rights.

Government goals in setting minimum wages are for equality and for reducing social inequality in the people of Indonesia. Equality is achieved by setting minimum wages so that there is no striking difference between the workers with the lowest wages and the workers with the highest wages. It is also achieved by guaranteeing workers/laborers get a decent wage as stated in Article 27 paragraph (2) of the 1945 Constitution of the Republic of Indonesia. According to Zulfadli Barus, "that, considering the weak position of workers towards their employers, there must be legal protection for workers". ${ }^{2}$ Because the birth of the concept of legal protection protection is from the emergence of imbalances between parties, where there are those who have a strong position and those who have a weak position, so that labor laws favor the weak who is right, but not the weak who is wrong.

The first element of the labor law system is the substance of labor law, while the substance of labor law is

\footnotetext{
${ }^{1}$ Made Darma Weda, Kriminologi, PT. Raja Grafindo Persada, Jakarta, 1996, p.32

${ }^{2} 366$ Zulfadli Barus, "Pengaruh Konfigurasi Politik Terhadap Politik Hukum Ketenagakerjaan di Indonesia Dihubungkan Dengan ModelModel Hubungan Industrial dan Sistem Outsourcing Menurut Undang-Undang Nomor 13Tahun 2003, No. 2: Vol. IV, Jurnal Supremasi Hukum, 2011, p.846-847
} 
the legislation concerning labor. For this reason, there must be conformity between all legal rules relating to employment. And conformity must be based on the legal science layer where there is a match between the rule of law, the theory of law and philosophy of law.

The great expectation for the synchronization of laws and regulations related to employment has not yet been implemented properly, because there are still a number of inconsistent legal rules relating to employment. For example, the protection of wage for workers is based on Article 27 paragraph (2) of the 1945 Constitution, that every citizen shall have the right to work and to earn a humane livelihood and Article 28 D paragraph (2) of the 1945 Constitution, that Every person shall have the right to work and to receive fair and proper remuneration and treatment in employment.

The government has established wage policies that protect workers as stated in Article 88 paragraph (2) of Law Number 13 of 2003. Then the wage system is further regulated in Government Regulation Number 78 of 2015 Article 43 paragraph (1) which states that the stipulation of minimum wages is carried out every year based on Decent Living Needs and by paying attention to productivity and economic growth.

The stipulation of minimum wages based on Decent Living Needs and productivity and economic growth, this means that minimum wages are highly dependent on productivity and economic growth in the current year. This also means that the determination of minimum wages for the next year is strongly influenced by productivity and economic growth in this year. Similarly, the annual minimum wage rate is also affected by economic conditions in the current year. Thus the right of workers to get a decent wage still has to depend on economic growth, even though economic growth is not the concern of workers.

\section{B. DISCUSSION}

\section{Politics of Law on Wage System}

Politics of law is basically a means of regulating and managing life in a nation of a country that is compatible with the ideology and values that live and develop in the country. ${ }^{1}$ Likewise in community life, there must be goals to be achieved, in reaching those goals, there are choices of means which can be used to produce the greatest possibility. Thus politics of law is also an activity of choosing a particular social goal or is a necessity to determine a choice regarding the objectives and ways to be used to achieve these objectives.

According to Solly Lubis, Politics of law needs to pay attention to three dimensions, politics, law, and culture, in which a set of values will be used as the basis of policies to regulate people's lives so that they reflect the noble values of a nation. ${ }^{2}$ As it is known that the strong and right parties, without legal protection they still can protect their own interests. But this is not the case with weak parties. That is why the term used is labor law, not employer law. Because those who are weak must get protection.

Based on the different bargaining position, the presence of a third party who is stronger than workers and employers is needed. The third party is the government who make public policy in the form of legislation as an embodiment of the state of law and welfare state as a means of organizing work relations between employers and workers so that they do not exploit each other, but more importantly, the employers do not exploit workers.

The human rights to work and have a decent livelihood in the regulation of minimum wages must also be upheld as the characteristic of economic democracy in Indonesia so that there is no need to look for references to foreign theories. According to Sunaryati Hartono, "The 1945 Constitution is wise in looking at economic needs and determining future legal policies". ${ }^{3}$ This can be seen in Article 27 paragraph (2) of the 1945 Indonesian Constitution which forms as the basis for determining minimum wages. In addition to social equality, the aim of regulating minimum wages is also intended to achieve fair remuneration. Yetniwati stated: To achieve a just wage law, requires several principles that must be met, including:

1. The legal and moral correlation is very important in the formation of law, legal substance and wage law enforcement. The highest moral in Indonesia is measured by the application of Pancasila values in industrial relations. Pancasila is the state ideology, the view of the Indonesian people, the highest source of law.

2. The right to receiving wages is born after the employment and ends when the employment ends.

3. Wages consist of several components which must be clearly specified, including compensation components consisting of basic wages, fixed allowances, and non-permanent benefits.

4. There should be no wage discrimination. Differences in wages for similar jobs or the same level of employment on the basis of sex differences, skin color differences, religion, ethnic group politics are prohibited.

5. Provision of wages must be humane, giving wages, in this case, means the amount of wage and the way to pay wages must respect workers as human beings who have human rights, which is the right to live a decent life.

\footnotetext{
${ }^{1}$ Muktie Fajar, Politik Hukum Di Indonesia, Kapite selekta Politik Hukum, Program Pascasarjana Universitas Brawijaya, Malang, 2001, p. 1

${ }^{2}$ M. Solly Lubis, Serba-Serbi Politik dan Hukum di Indonesia, Mandar Maju, Bandung, 1998, p. 49.

${ }^{3}$ Sunaryati Hartono, Op.Cit., p. 103.
} 
6. The government must protect workers' wages.

7. Provision of wages must pay attention to the balance between the interests of workers and employers.

8. There is an award for more productive workers.

9. Transparency in wage management, which is the company's economic policy in wage systems.

10. The parties, who intentionally or negligently, cause the loss of the other party must be subject to sanctions.

11. Priority rights over wages. Payment of wages must take precedence over other creditors.

12. Wage protection provided by legislation is the minimum or lowest protection.

13. Provide an opportunity to express opinions for stakeholders in making regulations related to labor law. ${ }^{1}$

Wage policy is also influenced by the government's strategy to make the investors willing or even like to invest in Indonesia. Because one of the country's sources of income to finance development is from the foreign investors who invest their capital in Indonesia. According to Sentosa Sembiring, "One of the factors that influence investors to invest their capital in Indonesia is the factor of cheap labor costs.".

Cheap labor costs can reduce production costs so employers can sell cheaper production goods and increase business competitiveness. Sentosa sembiring stated that: With the government setting low minimum wages it will attract investors to invest in Indonesia and have a positive impact on Indonesia, which:

a. In the foreign investment industry sector, it will be able to reduce foreign exchange requirements for imports;

b. Foreign investment increases state revenues in the form of taxes;

c. Foreign investment adds employment opportunities;

d. Technology transfer;

e. Foreign investment can be integrated with national development. ${ }^{3}$

Regulations regarding employment, especially regarding wages, are highly dependent on the politics of law and positive legal products of each country, including in Indonesia. Actually, the 1945 Constitution of the Republic of Indonesia as the highest regulation in the State of the Republic of Indonesia has guaranteed the basic rights of citizens in terms of decent livelihoods in accordance with humanity, as stated in Article 27 paragraph (2) of the 1945 Republic of Indonesia Constitution.

In Indonesia, the regulation regarding employment first arose because of an insistence from the ILO to ratify Convention No. 98 of 1949, which later became Law No. 18 of 1956 which regulated the issue of guarantee and legal protection for workers in handling income and wages that came from government and employers to protect workers. To ensure that workers get a decent wage, the government sets a minimum wage which is as the basis for employers to provide wages. The minimum wage in Indonesia was first regulated in 1971. Agusmidah et al stated that "It is remarkable that Indonesia has already known about the stipulation of minimum wages even in the 1970 s, since there were many more developed countries that have not yet regulated it.". 4

Minimum wages are an important element in the Indonesian social policy. Even Agusmidah et al explained that "What is unique in the system developed in Indonesia is the emphasis on wage proportionality, namely the linking of wages to" workers' needs ". In this case, it is also relevant that family members are economically dependent on laborers/workers and labor legislation that limits the right of employers to dismiss laborers/workers. ${ }^{5}$

According to Tianggur Sinaga, "The political journey of minimum wages began with the establishment of the Minimum Physical Needs (Kebutuhan Fisik Minimum - FKM) in 1956 through Tripartite consensus and nutritionists as a reference for calculating the minimum wage"6. Minimum wage policy was first introduced in the early 1970s, ${ }^{7}$ after the establishment of the National Wage Research Council (Dewan Penelitian Pengupahan Nasional - DPPN) based on Presidential Decree No. 85 of 1969 and the establishment of the Regional Wage Research Council (Dewan Penelitian Pengupahan Daerah - DPPD) by the Regional Government. Furthermore, Tianggur Sinaga explained that: the determination of the value of Minimum Physical Needs was carried out by the DPPD through research on prices in traditional markets which were conducted once a month for the DKI Jakarta area and once in 3 months for other provinces. The Regional Wage Research Council then delivered the results of the Minimum Physical Needs study and its conclusions regarding the minimum wage to the Governor, then recommended it to the Minister of Manpower. The National Wage Research Council then examines recommendations from the Governors before the Minister of Manpowerdetermined it to be a Minimum Wage

\footnotetext{
${ }^{1}$ Yetniwati, “Pengaturan Upah Berdasarkan atas Prinsip Keadilan”, Jurnal, No. 1:Vol.2, Mimbar Hukum, 2017, p. 86-90.

${ }^{2}$ Sentosa Sembiring, Hukum Investasi, Nuansa Aulia, Bandung, 2010, p. 23.

${ }^{3}$ Ibid.

${ }^{4}$ Agusmidah Bab-bab tentang Hukum Perburuhan Indonesia, Pustaka Larasan, Denpasar, 2012, p. 22.

${ }^{5}$ Ibid.

${ }^{6}$ Tianggur Sinaga, Kebijakan Pengupahan di Indonesia, Jurnal Ketenagakerjaan Vol. 3 - No.2 - Edisi Juli - Desember 2008 , p. 15.

${ }^{7}$ M. Rama, "The Consequences of Doubling the Minimum Wage:The Case of Indonesia", Industrial and Labor Relations Review, 54(4), 864881 .
} 
provision. ${ }^{1}$

Even though the policy on minimum wages has long been applied, normatively the minimum wage policy officially applies since the issuance of Minister of Manpower Regulation Number: PER-05/MEN/1989 concerning Minimum Wages. In this regulation, the minimum wage is the lowest basic wage excluding benefits provided to workers. A review of the amount of the minimum wage is held no later than 2 (two) years and the determination of minimum wages is based on the following considerations:

1. Minimum physical needs;

2. Consumer price index;

3. Expansion of employment opportunities;

4. Wages generally apply regionally;

5. The continuity and development of the company;

6. Level of Regional or National economic development.

The provisions of the minimum wage were then revised with the Regulation of the Minister of Manpower Number: PER-01/MEN/1990 concerning Amendment to the Regulation of the Minister of Manpower Number: PER-05/MEN/1989. In the revised provisions, the definition of minimum wages is "basic wages plus fixed allowances", with the provision of basic wages as low as $75 \%$ of the minimum wage.

In line with economic development in Indonesia, the components of the Minimum Physical needs are felt to be no longer appropriate and need to be studied to be refined, so that they become a component of Minimum Life Needs (Kebutuhan Hidup Minimum - KHM) stipulated through Minister of Manpower Decree No. 81 of 1995. Based on the Ministerial Decree, the component of the Minimum Life needs consists of:

1. Food and beverages, consisting of 11 (eleven) components.

2. Housing and Facilities, consisting of 19 (nineteen) components.

3. Clothing, consisting of 8 (eight) components.

4. Various needs, consisting of 5 (five) components.

The amendment of the Minimum Physical Needs component to the Minimum Life needs is harmonized with the issuance of the Minister of Manpower Regulation Number 3 of 1997 concerning Regional Minimum Wages which is only valid for 2 (two) years with the issuance of Minister of Manpower and Transmigration Regulation No: PER -01/MEN/1999 concerning Minimum Wages. In Permenakertrans No: PER-01/MEN/1999, the Minimum Wage is the lowest monthly wage consisting of basic wages including fixed allowances, valid for workers who have a work period of less than 1 (one) year. Determination of minimum wages is carried out by the Minister of Labor, and a review of the amount of minimum wage is held no later than every 2 (two) years.

Permenakertrans No: PER-01/MEN/1999 then revised through Kepmenakertrans No: KEP-226/MEN/2000 concerning the Amendment of the Articles of Labor Regulation of the Minister of Manpower No: PER01/MEN/1999 concerning Minimum Wages. In this decision, there were changes to several terms:

- Level I region minimum wage (Upah Minimum Regional Tingkat I - UMR Tk.I) was changed to Provincial Minimum Wages (Upah Minimum Propinsi).

- Level II region minimum wage (Upah Minimum Regional Tingkat II - UMR Tk II) was changed to District/City Minimum Wages (Upah Minimum kabupaten/Kota).

- Level I Region Sectoral Minimum Wage (Upah Minimum Sektoral Regional Tingkat I - UMSR I) was changed to Provincial Sectoral Minimum Wages (Upah Minimum Sektoral Propinsi - UMS Propinsi).

- Level II Region Sectoral Minimum Wage (Upah Minimum Sektoral Regional Tingkat II - UMSR Level II) are changed to District/City Sectoral Minimum Wages (Upah Minimum Sektoral Kabupaten/Kota - UMS Kabupaten/Kota).

Then the government issued Minister of Manpower and Transmigration Regulation Number 7 of 2013 concerning Minimum Wages in lieu of Permenakertrans No: PER-01/MEN/1999 Jo. Kepmenakertrans No: KEP$226 / \mathrm{MEN} / 2000$. The government's consideration in issuing these regulations was to protect workers' wages from falling at the lowest level due to labor market imbalances and to align minimum wage policies with regard to productivity and economic growth. Furthermore, it is also regulated regarding Provincial or District/City Minimum Wages, Provincial or District/City Sectoral Minimum Wages, and Minimum Wages for certain labor intensive industries.

According to Article 88 paragraph (1) of Law Number 13 of 2003, every worker has the right to receive wages or income that can fulfill the needs of a decent living for humanity. Whereas Article 88 Paragraph (2) of Law Number 13 of 2003 states that in order to realize income that fulfills decent living needs for humanity the government establishes wage policies that protect workers.

The provisions stipulated in Article 88 of Law No. 13 of 2003 above show that income that meets the needs of a decent living for humanity is the right of every worker, and the government is obliged to set minimum

${ }^{1}$ Ibid, p. 34-35 
wages to meet the decent living needs for workers and their families. In accordance with the explanation of Article 88 paragraph (1) of Law Number 13 of 2003, "Income that fulfills a decent livelihood is the amount of income earned by workers/laborers from the results of their work so that they are able to adequately fulfill the living needs of themselves and their family that include food and beverage, clothing, housing, education, health, recreation, and old age insurance".

Minimum wages are the lowest monthly wages consisting of basic wages and fixed allowances that are paid monthly or 2 (two) weekly in accordance with the agreement between workers and employers. When the terms have been agreed, employers are prohibited from paying lower wages than the determined wages. Minimum wage calculations in Indonesia are still limited to workers who have worked less than 1 (one) year and have single status.

The minimum wage setting mechanism is regulated in Law No. 13 of 2003 concerning Manpower and Government Regulation Number 78 of 2015 concerning remuneration. Both of these legislation stipulates that the Minimum Wage Determination is carried out by the Governor on the recommendation of the Wage Board which is based on Decent Living Needsand pays attention to economic productivity and growth and is directed towards achieving decent Living Needs according to the components and stages of achieving Living Needs. This parameter of wage determination is the main reason for the debate between workers and employers. The strikes to demand a minimum wage increase every year always raises its own problems.

The government has tried to improve the wage system by establishing wage policies that protect workers as stated in Article 88 paragraph (2) of Law No. 13 of 2003. The wage system is the Minimum Wage as stipulated in Government Regulation Number 78 of 2015 Article 43 paragraph (1) which states that the stipulation of minimum wages is carried out every year based on Decent Living Needs and by observing productivity and economic growth.

But the determination of minimum wages based on Decent Living Needs and productivity and economic growth is precisely what creates the problems. Because the stipulation of minimum wages that depend on productivity and economic growth in the current year makes the determination of minimum wages for the next year is strongly influenced by productivity and economic growth in this year. Similarly, the annual minimum wage rate is also affected by economic conditions in the current year. Thus the right of workers to get a decent wage still has to depend on economic growth, even though economic growth is not the concern of workers.

In Article 89 paragraph (2) Law No. 13 of 2003 states, that minimum wages are directed towards achieving decent living needs. Achieving Decent Life Needs is by comparing the amount of the Minimum Wage for Decent Living Needs in the same period. Achieving Decent Life Needs needs to be carried out in stages because Decent Living Needs are an increase of Minimum Life Needs which are largely determined by the level of ability of the business world. The provisions of Article 89 paragraph (2) are considered to have limited efforts to achieve the stages of decent living needs. Whereas the roadmap for achieving decent living needs set by the Governor acts a limit so that the minimum wage is not greater than the achievement of decent living needs, or the nominal value of the minimum wage is not above the decent living needs or not experiencing a significant increase.

The stipulation of the Minimum Wage by the Governor is carried out every year based on Decent Living Needs and by paying attention to productivity and economic growth. However, Government Regulation No.78 of 2015 concerning Remuneration also regulates the Minimum Wage calculation formula as follows: The current year Minimum Wage plus the multiplication of the current Minimum Wage with the sum of the current national inflation rate and current year's gross domestic product growth rate. Decent Living Needs is found in the current year's Minimum Wage.

Based on Government Regulation Number 78 of 2015 concerning remuneration, adjustments to the value of Decent Life Needs are directly corrected through the calculation of the current year Minimum Wage with the current national inflation rate. Decent Life Needs consist of several components of life necessities. In contrast to the previous system where each year, the wage council conducted a review of Decent Life Needs by conducting a market survey, in Article 43 paragraph (5) Government Regulation Number 78 of 2015, the Decent Life Needs component was reviewed within 5 (five) years..

Article 89 paragraph (2) of Law Number 13 of 2003 states that the stipulation of minimum wages is directed towards achieving decent living needs, the word "directed" causes minimum wages to not meet the decent living needs for workers and their families. This is because the calculation of the minimum wage has been "directed". In other words, the determination of minimum wage system as stipulated in Article 43 and Article 44 of Government Regulation No. 78 of 2015, minimum wages only results to the pattern of determining minimum wages rather than increasing workers' welfare. The Government Regulation Number 78 of 2015 concerning Remuneration is a translation of Article 97 Law Number 13 of 2003 concerning Labor. One of the provisions in this Government Regulation is the use of national inflation rate variables and economic growth as the main variables in calculating the increase of minimum wage. 


\section{Inconsistency of Government Policy Regarding Wages}

The first element of the labor law system is the substance of labor law. The substance of labor law is the legislation concerning labor. There must be conformity to regulations, including synchronization between labor law rules. Conformity must be based on the law. In accordance with the rule of law with legal theory and legal philosophy. In the condition of Indonesian labor regulations, there are still some legal rules that have not been consistent.

There are labor law rules specifically related to the regulation of inconsistent minimum wages. For example, the protection of each workers' wages comes from Article 27 paragraph (2) of the 1945 Constitution, that every citizen shall have the right to work and to earn a humane livelihood and Article 28 D paragraph (2) of the 1945 Constitution, that Every person shall have the right to work and to receive fair and proper remuneration and treatment in employment. "The description of fair and proper remuneration in employment is a decent income for humanity (Article 88 paragraph (1) of Law Number 13 of 2003). Wages are defined as: is the right of the worker/ labourer that is received and expressed in the form of money as remuneration from the entrepreneur or the employer to workers/ labourer, whose amount is determined and paid according to a work agreement, a deal, or laws and regulations, including allowances for the worker/laborer and their family for a job and or service that has been performed. (Article 1 number 30 of Law Number 13 of 2003).

However, this provision is not further elaborated in the implementing regulations. The amount of the minimum wage depends on the decent living needs. The decent living needs is the standard requirement for a single worker/laborer to be able to live physically fit for the needs of 1 (one) month (Article 1 number 1 of Minister of Manpower and Transmigration Regulation Number 13 of 2012 concerning Components and Implementation of Stages of Achieving Decent Living Needs).

This inconsistency also results in violations of the legal theory of decent wages. Article 3 ILO Convention No. 131: "The elements to be taken into consideration in determining the level of minimum wages shall, so far as possible and appropriate in relation to national practice and conditions, include:"

a.the needs of workers and their families, taking into account the general level of wages in the country, the cost of living, sosial security benefits, and the relative living standards of other sosial groups;

b.economic factors, including the requirements of economic development, levels of productivity and the desirability of attaining and maintaining a high level of employment.

If a rule of law contradicts a legal theory recognized as universal, then there is a high probability of a violation of its philosophy. Providing fair wages for workers/laborers has not been achieved. According to Asri Wijayanti, "The mismanagement of minimum wages at the dogmatic level of the law, legal theory and legal philosophy resulted in one of the demands of workers nationally to "tolak upah murah" (reject low wages). ${ }^{1}$

The inconsistency here is by the incompatibility between the legal substance of Law No. 13 of 2003 concerning Manpower. In the Black Law Dictionary, it says "locking consistency, not compatible with another fact or claim". According to Agusmidah, "In the 2004-2009 RPJMN it was stated that politics of law issues generally concern the issue of legal substance which is characterized by the inconsistency of laws and regulations". ${ }^{2}$

One-way substantive law with Satjipto Rahardjo's view concerning progressive law:

1) The law is for humans, not the other way around. Therefore, even though the law starts from the text of the law, then the legal work is taken by humans and used to make decisions;

2) Implementing the law is creating justice in society;

3) The judge is not a legislator, because the judge's duty is adjudicating or investigating or judging. ${ }^{3}$

To achieve responsive Labor Law one of them is by eliminating inconsistencies in labor law itself. The reason for this inconsistency can be seen at least from the absence of an academic text on Law No. 13 of 2003 concerning Manpower, which resulted in the law being drafted by violating the principles and procedures for compiling and making an appropriate law. Besides, the evidence of other inconsistency is that the law still rests on a past political culture, repressive law during the Dutch colonial period, and autonomous law during the Old and New Order Regulations.

The purpose of the law is the justice, the expediency, and the certainty of law to achieve the welfare of society. According to Dominikus Rato's opinion: for legal purposes to be reached, it is necessary that strict, clear, non-interpretive, unambiguous, rules to be consistently applied, which are called legal certainty.

Therefore, several requirements must be met:

a. the law can not be retroactive;

b. legal decisions should not be confused;

c. legal decisions can not take favoritsm; and

\footnotetext{
${ }^{1}$ Asri Wijayanti, Menuju Sistem Hukum Perburuhan Indonesia yang Berkeadilan, Arena Hukum, Vol. 6: No.3, Desember 2012.

${ }^{2}$ Agusmidah, Op.Cit., p. 24

${ }^{3}$ Satjipto Rahardjo, Negara Hukum yang Membahagiakan Rakyatnya, Genta Publishing, Yogyakarta, 2009, p. 23
} 
d. social and political conditions must be stable and normal. ${ }^{1}$

The values of legal certainty in labor law must be one with the value of justice and expediency. Legal certainty in the regulations will be obeyed by workers and employers if it is beneficial and gives them justice. The role of officials in the ministry in charge of employment contributes greatly to the achievement of legal objectives that are prosperous for workers and employers. The workers should increase their expertise with the help of the government and employers to work professionally, so that they will benefit to both workers and employers.

While the entrepreneurs, not only manage to increase the progress and profits of the company but also can increase the income of workers. The inconsistency and uncertainty of legislation in the field of wages, are the cause of conflicts between workers, employers, and the government. The problem is the difference of opinions/views on wages. According to Cosmos Batubara, "Wages have long been in the spotlight of various groups involved in industrial relations because the wages position is very strategic". ${ }^{2}$

The feasibility of minimum wages as part of the basic rights of workers is faced with the consistency of the implementation of the law and the reality of life that is considered feasible or even prosperous for workers. The concept of eligibility for wages reflects a dilemma between the welfare referred to in regulation and factual wellbeing. As a stakeholder who is responsible for the welfare of the people, the Indonesian government has not prioritized the field of labor at the point of prosperity expected by workers/laborers. This is understandable because Indonesia does not only stop on the island of Java and its surroundings.

Minimum wage policy, in addition to regulations that regulate in a macro area (in the form of laws), the government also makes regulations in the form of government regulations, ministerial regulations and also in the form of ministerial decrees. In addition to wage policies that regulate the mechanism for determining wages in the labor market, the government also stipulates wage policies that protect workers, this policy is carried out by the government to realize income that can fulfill decent livelihoods for humanity.

Legislation is a part of law that is intentionally made by state institutions. It did not appear suddenly, but it was made for certain purposes and reasons. Considering the consistency and correlation between what is determined as politics of law and what is wanted in achieving the goal, politics of law can be distinguished in two dimensions.

The first dimension is the politics of law which is the basic reason for holding a law. This politics of law with the dimension of the basic reason like this, according to Hikmahanto, is referred to as "basic policy". The second dimension of the politics of law is the purpose or reason behind the enactment of a law, which is then referred to as the enactment policy. Tyocronisilicus stated that "Through this enactment Policy, it can be identified the various instrumental policies functioning at the time of the laws in Indonesia are enacted. ${ }^{3}$

A legal norm will only become important if the legal norms apply and are binding on the subject matter they regulate. Likewise, a law will only be said to be effective when the law is generally binding according to its purpose. Legal norms can be said to apply be valid if they are not solely imposed by a power that has authority. The application of a legal norm is strongly influenced and determined by many factors. ${ }^{4}$ Jimly assiddiqie further stated, "that the legal norms in question can be considered valid because of philosophical considerations, juridical considerations, political considerations, or administrative considerations". 5

Whereas Bruggink stated, that the implementation of norms was differentiated into:

a. factual enactment or empirical enactment;

b.normative enactment or formal enactment;

c. evaluative enactment. ${ }^{6}$

The validity of a norm in the sense of applying a legal method, according to Meuwissen, requires:

- Social or factual enactment. In this case, the legal method is in fact accepted and enforced by the general public including by accepting sanctions if any person does not abide by it.

- Juridical enactment. In the event that the rule of law is made through the correct procedures and does not contravene other regulations, especially with higher regulations.

- Moral enactment. In this case, to be valid, the legal method should not violate human rights or contravene the rules of natural law. ${ }^{7}$

\footnotetext{
${ }^{1}$ Dominikus Rato, Filsafat Hukum., Mencari, Menemukan, dan Memahami Hukum, Penerbit LaksBang Justitia Surabaya, Surabaya, 2011, p. 150-151.

${ }^{2}$ Cosmas Batubara, "Menyegarkan Kembali UMP dan Upah yang Adil", Paper Seminar Kemenakertrans, Hotel Ciputra, Jakarta, 15-16 Maret 2012, p. 2

3 Tyokronisilicus, 2010, Peranan Politik Hukum Dalam Pembentukan Peraturan Perundangan-Undangan, https://tyokronisilicus.wordpress.com/2010/05/04/

${ }^{4}$ Jimly Assiddiqie, Perihal Undang-Undang, Radja Grafindo Persada, Jakarta, 2011, p. 166

${ }^{5}$ Ibid.

${ }^{6}$ JJH Bruggink, Refleksi Tentang Hukum, Citra Aditya Bakti, Bandung, 1996, p. 149

${ }^{7}$ Meuwissen, in Munir Fuadi, Teori-Teori Besar (Grand Theory) Dalam Hukum, Kencana Prenada Media Gruop, Jakarta, 2013, p. 124
} 
The politics of law that are more concerned with enactment policies but ignoring basic policies are one of the main factors in the emergence of inconsistencies. Indeed, politics of law is useful to find laws that really fit between expectations and reality, between rules (Article) in the Law with the rules below (implementing regulations), between law in book and law in action. ${ }^{1}$

Institution that forms legislation is referred to as a system, so the content produced cannot be contradictory to one another and in its formation must open for input from the fields which are then channeled into the community. in the aspirations of the Indonesian people, either ideas, feelings, inventions, or thoughts creates reality in life as a construction built by the community itself, thus every process of formation in the law must not conflict with the legal ideals that have been agreed together. The law must be understood as the binding base in the formation of laws and regulations, the value aspect is increasingly important and the regulation is intended to be implemented into a product that is more operational and technical in implementation. ${ }^{2}$

What is meant by formal rational law in this case is that the law is intellectually must be consistent, namely consistent between factors such as legal rules, legal principles, legal standards, and legal concepts (legal concepts). The meaning of substantive rational law is the rule of law that is in accordance with ideology and values that change in society.

What is meant by formal rational law, in this case, is that the law must be consistent intellectually, it means to be consistent between each factor such as legal rules, legal principles, legal standards, and legal concepts. The meaning of substantive rational law is the rule of law that is in accordance with ideology and values that always change in society". ${ }^{3}$ There are still many overlapping, inconsistent and conflicting laws and regulations between equal regulations with one another, between central and regional regulations, and between lower regulations and other regulations above them.

Regulations in the field of employment in Indonesia have not yet come to the codification of Labor Law. Even though there is no important aspect that must be considered, the codification of Labor Law is to maintain consistency and synchronization between one article and another, both in the same law or not. There are still rules that cannot be applied, due to inconsistencies including minimum wages, Specific Time Work Agreements (PKWT) and outsourcing.

Legal certainty is a problem that often arises because the employer tends to employ workers with work agreements at a certain time, while workers prefer work agreements for an indefinite or permanent time because they want job security. This fact shows that many companies decide to lay off permanent workers to then recruit them again with a certain time contract. In such situations, the worker has no choice but to accept the offer.

Since the enactment of Law No. 13 of 2003, outsourcing workers became booming. This is because entrepreneurs in the framework of efficiency feel safe if the outsourced workers are from service companies so that the one who is responsible for the outsourced workers is the service company. The entrepreneurs feel that they are backed up by Article 66 paragraph 2 a which states that between worker service companies there must be a working relationship with workers placed in the user's company.

On the other hand, the outsourcing laborers also feel that they are backed up by Article 1 point 15 which states that their working relationship is not with a service company but with a user company. This is due to the element of the existence of wages, employment and orders only in relation to the user company not with the worker service company. According to R. Goenawan Oetomo, "these two articles also cause legal uncertainty for employers and workers. Many companies terminate their employment with their workers and are subsequently recruited through worker service companies (outsourcing workers) ". 4

The determination of the minimum wage in the last year has created a polemic, this is due to the synchronization of several wage articles in Law No. 13 of 2003 and Government Regulation no. 78 of 2015. In Article 88 of Law No. 13 of 2003 affirms that every worker/laborer has the right to obtain income that fulfills decent living needs. To create income that fulfills a decent livelihood, the government establishes wage policies that protect workers/laborers. The wage policy is the minimum wage, and the government sets minimum wages based on decent living needs by paying attention to productivity and economic growth.

Furthermore, the Government Regulation No. 78 of 2015 also emphasizes that, wage policies are aimed at achieving an income that meets decent living needs for workers/laborers, and the wage policy includes the minimum wage (Article 3 of Government Regulation No. 78 of 2015). Proper income is the amount of income earned by workers/laborers from the results of their work performance so that they are able to meet the living needs for themselves and their families.

Whereas in Government Regulation No. 78 of 2015 Article 42 paragraph (1) states that the minimum wage

\footnotetext{
${ }^{1}$ Hikmahanto Juwana, Politik Hukum Undang-Undang Bidang Ekonomi di Indonesia, Jurnal Hukum, Vol. 01 No. 1 Tahun 2005 , Program Magister Ilmu Hukum Pascasarjana USU Medan, p. 28

2 Indrayadi Purnama Saputra, Hukum UGM, 2012, Tujuan Negara-Politik Hukum dan Perundang-Undangan, dalam http://indrayadipurnamasaputra.blogspot.com/2012/06/

${ }^{3}$ Agusmidah, Dilematika..., op.cit, p.24

${ }^{4}$ Goenawan Oetomo, Pengantar Hukum Perburuhan dan Hukum Perburuhan di Indonesia, Grhadika Binangkit Press, Jakarta, 2004, p. 15
} 
applies only to workers/laborers with a work period of less than 1 (one) year. Determination of minimum wages is carried out every year based on the needs of decent living and by paying attention to productivity and economic growth, and the necessities of decent living are the standard needs of a single worker/laborer to live comfortably for one month.

Regulations regarding wages basically consist of two major parts, they are: 1) regulations relating to the wage setting mechanism (minimum), 2) regulations related to wage protection. ${ }^{1}$ The minimum wage setting mechanism regulated in several articles concerning remuneration does not reflect or does not represent wage policy. The spirit and purpose of the wage policy is to protect workers/laborers to get a decent income so that they are able to adequately meet the living needs of workers/laborers and their families.

According to Catherine Saget, "the study of legislation in Indonesia confirms that minimum wages are not just a minimum wage". ${ }^{2}$ The law, for example, provides exceptions to companies that are unable to pay the minimum wage to their workers. This practice is clearly contrary to the definition of minimum wages as mandatory and not an option. As stated by Mudji Handojo, Director General of Oversight and K3 Norms of the Indonesian Ministry of Manpower and Transmigration, as quoted in Tabloid Lembur, December 2009 Edition, the root of the minimum wages is that the minimum wage policy cannot be implemented in the field, meaning, making it difficult to enforce the law. ${ }^{3}$

In accordance with the rules, the minimum wage is set by the Governor through a decree, the entrepreneur must automatically abide to the rules, even violating this rule is a crime, but strangely there is a regulation that states that if the company is not able to meet the minimum wage, the company may file a suspension. So according to Handojo, the government also contributes to this wage crime, it is actually difficult because we are trapped in minimum wage regulations where the policy cannot be implemented in the field.

Aloysius Uwiyono considered that the government and the House of Representatives were too imposing the Law No. 13 of 2003 concerning Manpower. Moreover, the draft law is not supported by academic manuscripts, so that the substance of the articles is full of "not applicable" inconsistencies, which would lead to legal uncertainty. Of course, this will hinder industrial relations in the workplace, both employers and workers become uncertain about which rules should be applied. ${ }^{4}$

Environmental diversity and social status cannot be accommodated in the form of adequate regulations for all wage interests in Indonesia. Pierre Laliberte stated that:

"At the policy level, the issue of the miminum wage remains deeply controversial as it introduces moral considerations as to what constitutes minimal and fair compensation in a given economyand the role of minimum wage in ensuring that people earn enough through their labour to afford to sustain themselves and their families. Yet this entry of "morality" in a discipline that prides that sees itself as scientific and positivistic is always bound to be contentious especially if it goes againts the "law of gravity" of neoclassical economics: a rise in price (wages) must necessarily in a drop in demand." 5

As a result of the lack of synchronization of rules regarding minimum wages, it can put the Governor as a government representative in the province in a dilemma situation regarding determining minimum wages in each region. This situation raises an action to indirectly use discretion in setting minimum wages.

The Chamber of Commerce and Industry considers that the demonstrations that often occur in Indonesia do not dampen the intention of entrepreneurs to invest in the country. Because for them, the inconsistency of government policy is more terrible than the demonstrations that lately often occur. Chairman of the Chamber of Commerce and Industry, Rosan Perkasa Roeslani revealed, the demonstration is something natural in a democratic country like Indonesia. According to Roeslani, inconsistent government policies will actually be able to reduce production capacity.

\section{CONCLUSION}

According to Article 88 paragraph (1) of Law Number 13 of 2003, every worker has the right to receive wages or income that can fulfill the needs of a decent living for humanity. Whereas Article 88 Paragraph (2) of Law Number 13 of 2003 states that in order to realize income that fulfills decent living needs for humanity the government establishes wage policies that protect workers. However, the Minimum Wage Determination based on Government Regulation Number 78 Article 43 paragraph (1) which states that "minimum wage fixing is carried out every year based on Decent Living Needs and by paying attention to productivity and economic growth" has created problems due to inconsistent government attitudes.

\footnotetext{
1 Sidauruk, Kebijakan Pengupahan di Indonesia: Sebuah Tinjauan Kritis da Usulan Perubahan Menuju Upah Layak, PT. Bumi Intiama Sejahtera, Jakarta, 2011 , p. 9

${ }^{2}$ Catherine Saget, Penentuan Besaran Upah Minimum di Negara Berkembang Kegagalan dan Pemecahan Masalah, Program Keadaan Kerja dan Ketenagakerjaan (TRAVAIL) Kantor Perburuhan Internasional 4, Route des Morillos CH-1211 Jenewa, p. 12

${ }^{3}$ Tabloid Lembur, Perang Upah 2009, Edisi 20-Bulan Desember 2009, p. 7

${ }^{4}$ A. Uwiyono, UU Ketenagakerjaan-UU Kanibalisme, di http://www.hukumonline.com

${ }^{5}$ Pierre Laliberte, Sosial Justice and Growth: The Role of the Minimum Wage, International Journal of Labour Research 2012. Vol. 4 , p. 26
} 
The point of the problem is "paying attention to economic growth". With the phrase that Determination of minimum wages depends on economic growth in the current year. So the determination of minimum wages for next year is strongly influenced by economic growth in the current year. Even though the component of economic growth and/or inflation is a government obligation and does not concern the workers. Therefore establishing the amount of minimum wage by basing on economic growth, and putting aside the necessities of decent living based on market surveys, are not the acts of protecting workers, it does not reflect justice and the achievement of labor welfare as the politics of law ideals of the wage system adopted by Indonesia.

\section{Bibliography}

Book-Journal:

Assiddiqie, Jimly, Perihal Undang-Undang, Radja Grafindo Persada, Jakarta, 2011.

Agusmidah, Bab-bab tentang Hukum Perburuhan Indonesia, Pustaka Larasan, Denpasar, 2012.

Bruggink, JJH, Refleksi Tentang Hukum, Citra Aditya Bakti, Bandung, 1996.

Barus, zulfadli, "Pengaruh Konfigurasi Politik Terhadap Politik Hukum Ketenagakerjaan di Indonesia Dihubungkan Dengan Model-Model Hubungan Industrial dan Sistem Outsourcing Menurut UndangUndang Nomor 13Tahun 2003, No. 2: Vol. IV, Jurnal Supremasi Hukum, 2011.

Batubara,Cosmas, "Menyegarkan Kembali UMP dan Upah yang Adil", Paper Seminar Kemenakertrans, Hotel Ciputra, Jakarta, 15-16 Maret 2012.

Fajar, Muktie, Politik Hukum Di Indonesia, Kapite selekta Politik Hukum, Program Pascasarjana Universitas Brawijaya, Malang, 2001.

Fuadi, Munir, Teori-Teori Besar (Grand Theory) Dalam Hukum, Kencana Prenada Media Gruop, Jakarta, 2013.

Juwana, Hikmahanto, Politik Hukum Undang-Undang Bidang Ekonomi di Indonesia, Jurnal Hukum, Vol. 01 No. 1 Tahun 2005, Program Magister Ilmu Hukum Pascasarjana USU Medan.

Lubis, M.solly, Serba-Serbi Politik dan Hukum di Indonesia, Mandar Maju, Bandung, 1998.

Laliberte, Pierre, Sosial Justice and Growth: The Role of the Minimum Wage, International Journal of Labour Research 2012. Vol. 4.

Milano, Aulia, Politik Hukum Pengupahan: Suatu Kajian Terhadap Penetapan Upah Minimum Kabupaten (UMK), No. 1: Vol: 10, Rechtldee Jurnal Hukum, 2016.

Oetomo, Goenawan, Pengantar Hukum Perburuhan dan Hukum Perburuhan di Indonesia, Grhadika Binangkit Press, Jakarta, 2004.

Rahardjo, Satjipto, Pemanfaatan Ilmu-Ilmu Sosial Bagi Pengembangan Ilmu Hukum, Alumni, Bandung, 1977. -Negara Hukum yang Membahagiakan Rakyatnya, Genta Publishing, Yogyakarta, 2009.

Rato, Dominikus, Filsafat Hukum., Mencari, Menemukan, dan Memahami Hukum, Penerbit LaksBang Justitia Surabaya, Surabaya, 2011, p. 150-151.

Sidauruk, Kebijakan Pengupahan di Indonesia: Sebuah Tinjauan Kritis da Usulan Perubahan Menuju Upah Layak, PT. Bumi Intiama Sejahtera, Jakarta, 2011.

Saget, Catherine Penentuan Besaran Upah Minimum di Negara Berkembang Kegagalan dan Pemecahan Masalah, Program Keadaan Kerja dan Ketenagakerjaan (TRAVAIL) Kantor Perburuhan Internasional 4, Route des Morillos CH-1211 Jenewa.

Sunyoto, Danang, Hak dan Kewajiban bagi Pekerja dan Pengusaha, Pustaka Yustisia, Yogyakarta, 2013.

Tabloid Lembur, Perang Upah 2009, Edisi 20-Bulan Desember 2009, http://www.hukumonline.com, A. Uwiyono, UU Ketenagakerjaan-UU Kanibalisme,

Tyokronisilicus, 2010, Peranan Politik Hukum Dalam Pembentukan Peraturan Perundangan-Undangan, https://tyokronisilicus.wordpress.com/2010/05/04/.

Weda, Made Darma, Kriminologi, PT. Raja Grafindo Persada, Jakarta, 1996. 